posterior lateral angles as follows: Segment 2, a short hair; segment 3, a long hair; segment 4, a long hair; segment 5, two long hairs; segment 6, two long hairs; segment 7, a long hair; segments 3 to 7 each with a long hair arising just mediad of the lateral angles; segment 8 with two long hairs laterally; a pair of long, subterminal hairs before the deeply emarginate posterior tip.

Type: Catalogue No. 21367. U. S. Nat. Mus.

\title{
NOTES ON SOME NEW SPECIES OF THE GENUS
} DIOCTRIA (ASILIDA).

\author{
By Nathan Banks, \\ Museum of Comparative Zoology, Cambridge, Mass.
}

Our Eastern specimens of the genus Dioctria have all been placed in the species albius Walker. In examining our specimens I note, however, two types of male genitalia. In one, the northern form, the superior plate has two broad lobes, sometimes standing out flat, sometimes rolled down over the other parts; in the other more southern specimens the superior plate is divided into two long tapering parts ending in a knob-like enlargement, with a tooth on the inner surface and a pencil of yellow hair on the outer edge. The northern form is the true albius Walker; it has the third antennal joint short, and with a very short style; the mystax is black; the body is rather longer than in the southern forms. The southern forms I divide into two species, one with the antennæ like D. albius; the other with the third joint and style much longer; both are new.

\section{Dioctria brevis sp. nov.}

Black, bronzy as in D. albius, and in general similar to that species; the third antennal joint barely if any longer than in D. albius. It differs at once, in the shape of the superior plate of the male genitalia, having two long tapering divisions, rather swollen at their tips, with a sharp, slender tooth on the inner side shortly before tip, and on the outer side a pencil of yellow hair.

Specimens are 8 to $10 \mathrm{~mm}$. long, and come from Sea Cliff, N. Y.; Medina, Ohio; Englewood, N. J.; and north fork Swannanoa River, Black Mountains, N. C.

Type: M. C. Z. 10032. 
Dioctria longicornis sp. nov.

This in appearance is similar to D. brevis; in some the mystax is mostly white, and the pleural piece in front of wing-base is not often pollinose. The male genitalia are closely similar to those of $D$. brevis, but the branches of the lateral appendages are not just the same. It differs, however, at once from $D$. brevis and also $D$. albius in the very much longer antennæ; the third joint being much longer than the first and second together, and the style longer and about as thick as the third joint.

Specimens are $7\left(\sigma^{x}\right)$ to $9(\%) \mathrm{mm}$. long, and all I have are from the vicinity of Washington; Chain Bridge, Glencarlyn, and Dead Run, Virginia.

Type: M. C. Z. 10033.

Dioctria longicornis var. tibialis var. nov.

Two males differ from the type in having all the tibiæ reddish on basal half. They are from Chain Bridge, Va.

Type: M. C. Z. 10034.

Dioctria media sp. nov.

Black, face golden, mystax black, thorax and abdomen more hairy than in $D$. albius, thorax reddish pollinose much as in $D$. albius; the third antennal joint and the style about as in D. albius; the body shorter than in D. albius; the male genitalia have the superior plate a slender, finger-like projection, about four times as long as broad, with parallel sides and undivided; the lateral arms of the genitalia are very much shorter and heavier than in either D. albius or D. brevis. Length 7 to $8 \mathrm{~mm}$.

Five specimens from Sonoma County, Calif., 4 July (Osten Sacken), San Raphael, Calif. (Osten Sacken) and California (H. Edwards). These were doubtfully referred to D. albius by Osten Sacken, but the male genitalia show them to be very distinct.

Type: M. C. Z. 10037.

Dioctria pleuralis sp. nov.

Black, face golden to white, mystax pale; third joint of the antennæ very long, the style about one-fourth of the third joint; vertex shining, the thorax with mostly yellowish hairs. On the pleura 
from base of wings to front coxæ is a yellowish pollinose stripe. Legs all pale yellowish, the hind basitarsus very large, as long as the next three joints together; the mesothorax has the hind lateral pieces yellowish, and the metathorax is golden pollinose; abdomen dull rufous, with indistinct black on each segment, mostly near the middle, first segment wholly black. Wings moderately fumose. Length, $8 \mathrm{~mm}$.

One female from Los Angeles, Calif. (Clark coll.).

Differs from D. rubidus in the pale coxæ, and shape of style, from $D$. pusio in color of the abdomen and thorax, and the shape of the style.

Type: M. C. Z. 10035.

Dioctria flavipes sp. nov.

Runs to no. 6 in Back's table. The legs wholly pale yellow (including coxæ); the mystax pale; the abdomen black, largely reddish below; the second segment has a reddish spot on the sides in front, hardly seen from above, the third segment has a basal reddish band, the fourth segment with both basal and apical bands of reddish, the fifth and sixth segments with reddish at tip. The hind basitarsus is large, and as long as the next three joints together; the body has few, short hairs. Length $6 \mathrm{~mm}$.

One of from Yakima, Washington, 2 July 1882 (Samuel Henshaw coll.).

Type: M. C. Z. 10036.

\section{Dioctria sackeni Will.}

The specimen from the White Mountains referred to by Williston in the Osten Sacken coll. is a male and has the genitalia similar to those of albius, but the parts are close together and may differ in details not clearly visible in this specimen. 

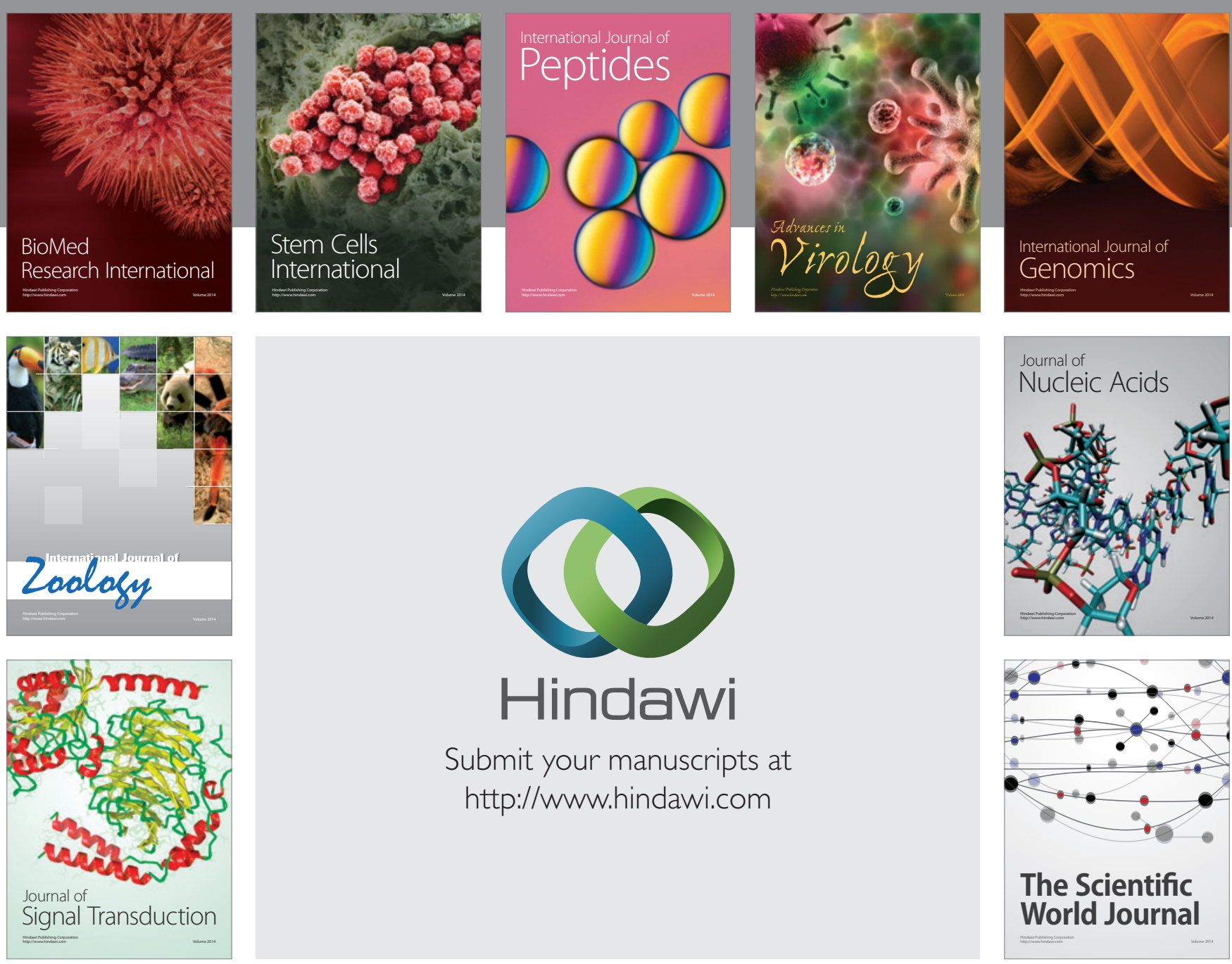

Submit your manuscripts at

http://www.hindawi.com
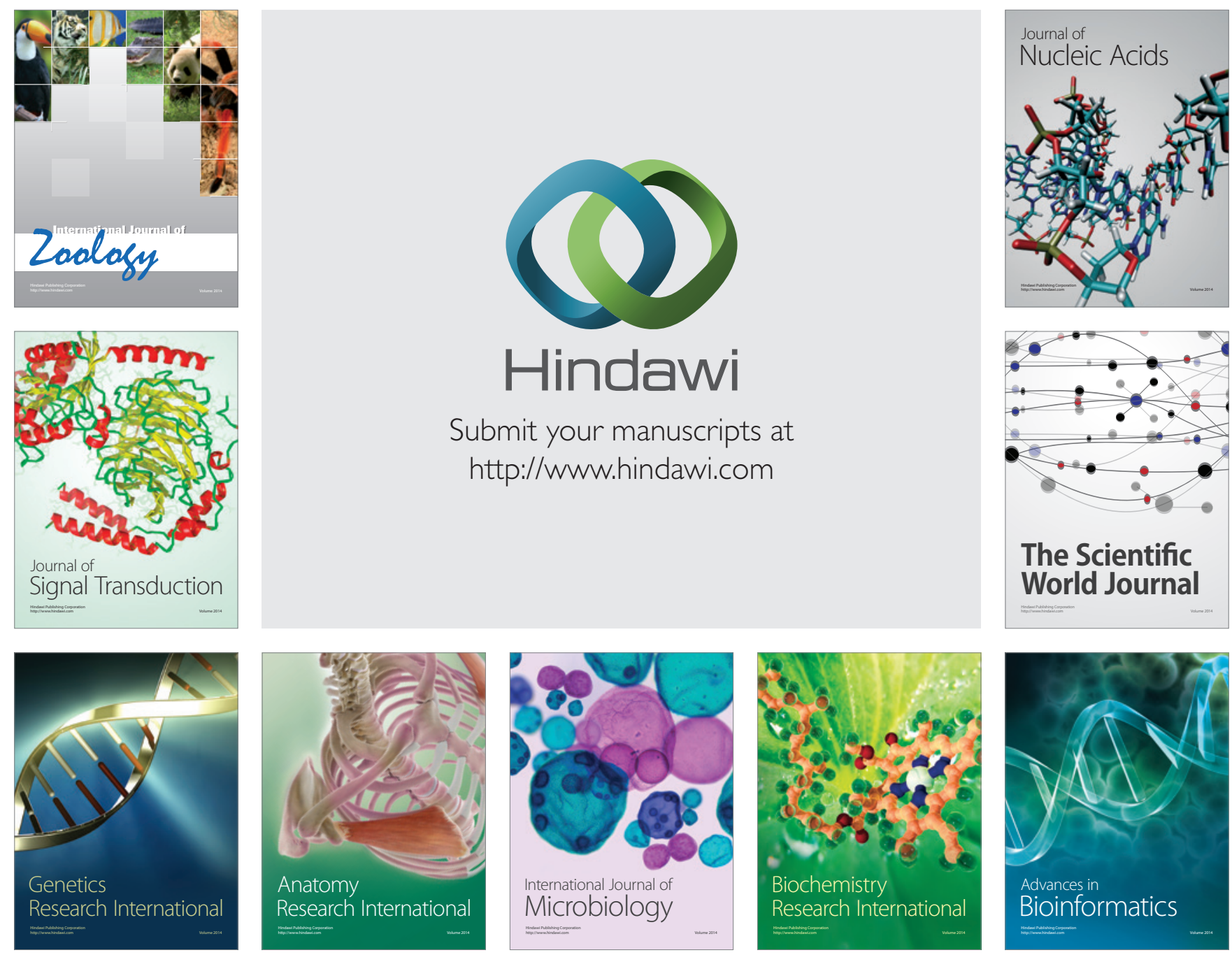

The Scientific World Journal
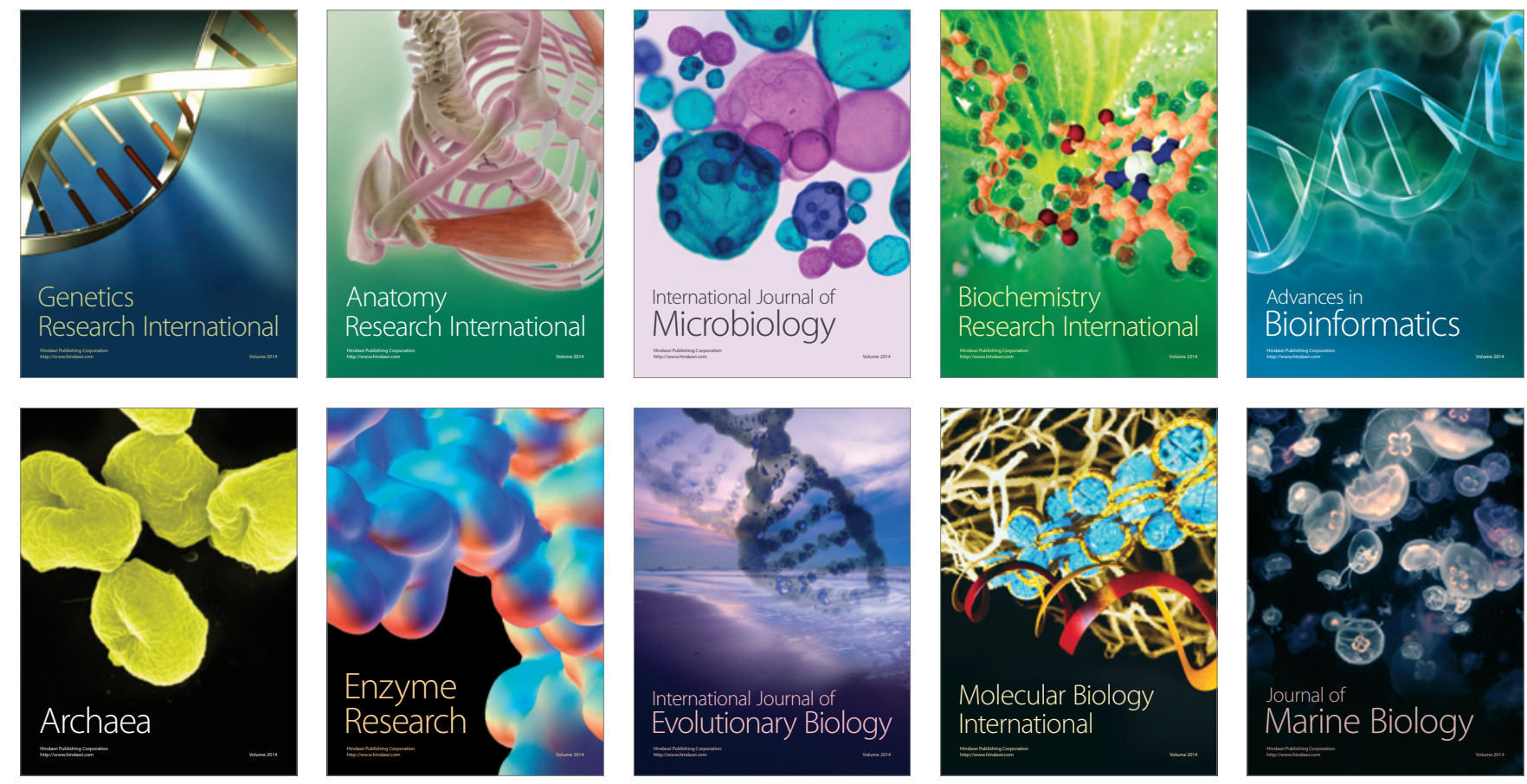